\title{
IDENTIFICATION OF SCHOOL LEADERSHIP STRATEGY IN SUPPORTING STUDENTS LEARNING FROM HOME DURING PANDEMICS
}

\author{
Herlan Suherlan ${ }^{1}$, Arnadi $^{2}$, Fahrina Yustiasari Liriwati $^{3}$, Kafrawi $^{4}$, Abd. Syahid $^{5}$ \\ Sekolah Tinggi Pariwisata Bandung, Indonesia \\ ${ }^{2}$ Institut Agama Islam Sultan Muhammad Syafiuddin Sambas, Indonesia \\ ${ }^{34,5}$ STAI Auliaurrasyidin Tembilahan Riau, Indonesia \\ hel@stp-bandung.ac.id, drarnadi2016@gmail.com, fahrina.yustiasari@stai-tbh.ac.id \\ kafrawi@stai-tbh.ac.id, abd.syahid@stai-tbh.ac.id
}

Received: 07-08-2021 Revised: 30-10-2021 Accepted: 07-11-2021

\begin{abstract}
Identifying school leadership strategies to support students learning from home during the pandemic is the core objective of this study. To answer the problem above, we have reviewed dozens of publications interested in discussing educational disruption during the outbreaks where the effect of the disruption forces students to study from home with all the problems that arise. We get the data from an online search, and we study it with a phenomenological approach. We evaluate the data with a coding system to know what and how school leadership responds to the pandemic. Based on the data and the discussion, we found that many things must and have been done by the school that does not have to wait for the direction of policy superiors from the central state. The support provided is, for example, teachers and school boards assisting students and guiding how to prevent students and parents from panicking through the disrupted period of the pandemic. Schools do not force students with assignments and work, but teachers should encourage collaborative learning with parents while maintaining progress. Thus, we hope this study is helpful to many parties.
\end{abstract}

Keywords: leadership, Pandemic, Online training, School and publication review

\section{Abstrak}

Mengidentifikasi strategi kepemimpinan sekolah untuk mendukung siswa belajar dari rumah selama pandemi adalah tujuan inti dari penelitian ini. Untuk menjawab permasalahan di atas, telah kami ulas puluban publikasi yang tertarik membahas tentang gangguan pendidikan pada masa wabah dimana efek gangguan tersebut memaksa siswa untuk belajar dari rumah dengan segala permasalahan yang muncul. Kami mendapatkan data dari pencarian online, dan kami mempelajarinya dengan pendekatan fenomenologis. Kami mengevaluasi data dengan sistem pengkodean untuk. mengetahui apa dan bagaimana kepemimpinan sekolah merespons pandemi. Berdasarkan data dan diskusi, keami menemukan bahwa banyak hal yang harus dan telah dilakukan oleh sekolah yang tidak harus menunggu arahan dari atasan kebijakan dari negara pusat. Dukungan yang diberikan misalnya, guru dan dewan sekolab membantu siswa dan membimbing bagaimana mencegah siswa dan orang tua panik melahi masa pandemi yang terganggu. Sekolah tidak memaksa siswa dengan tugas dan pekerjaan, tetapi guru harus mendorong pembelajaran kolaboratif dengan orang tua sambil mempertahankan kemajuan. Oleh karena itu, kami berbarap penelitian ini bermanfaat bagi banyak pibak.

Kata Kunci : Kepemimpinan, Pandemi, pembelajaran daring, sekolah dan telaah publikasi. 


\section{INTRODUCTION}

Since the pandemic hit the world, all lives have been affected, including education, so educators everywhere are looking for safer strategies and frameworks to continue to support the learning process even from a distance. ${ }^{1}$ Because students learn face-to-face methods in traditional schools or youth environments, it is impossible since the world body confirmed the danger of the coronavirus threatening the school community. ${ }^{2}$ The solution is that many schools, especially in cities, have suddenly switched to online learning methods such as online learning assisted by the internet and self-taught. So, in line with that, experts and learning policymakers began to look for alternatives so that learning activities continued even though there was little guidance and leadership from schools on how to continue learning as well as a few leadership directions from schools that connect students and families to be able to best practice learning methods that are following the typical disruptions caused by Covod-19. ${ }^{3}$ So, for that, we need a solution on effectively providing online education services, focusing on strategies for how schools can support students, and guardians must handle the use of technology and adaptation that is easy to follow.

Furthermore, teachers can use them correctly according to learning needs in anticipation of situations disrupted by the pandemic. Therefore, a solution is needed in the form of a strategy that is assistance from schools to be transferred to students during the pandemic. Some of these owned tools cannot be used, some of which only rely on online learning but are not optimal. ${ }^{4}$

This study recognizes evidence of field practice in other educational contexts in supporting schools on school leadership in serving online learning, which has become a government policy solution and offers leadership guidance to students and their guardians during this virtual learning period. ${ }^{5}$ Standard leadership guidance from schools must be given considering that learning must have a firm and effective strategy and framework to support

1 Aras Bozkurt dkk., "A global outlook to the interruption of education due to COVID-19 pandemic: Navigating in a time of uncertainty and crisis," Asian Journal of Distance Education 15, no. 1 (2020): 1-126. Purniadi Putra dkk., "The Students Learning from Home Experiences during Covid-19 School Closures Policy In Indonesia," Jurnal Iqra': Kajian Ilmu Pendidikan 5, no. 2 (5 September 2020): 30-42, https://doi.org/10.25217/ji.v5i2.1019.

2 Alain García Vazquez dkk., "Image-guided surgical e-learning in the post-COVID-19 pandemic era: what is next?," Journal of Laparoendoscopic \& Advanced Surgical Techniques 30, no. 9 (2020): 993-97. Aslan Aslan dkk., “TEACHER'S LEADERSHIP TEACHING STRATEGY SUPPORTING STUDENT LEARNING DURING THE COVID-19 DISRUPTION," Nidhomul Haq: Jurnal Manajemen Pendidikan Islam 5, no. 3 (21 November 2020): 321-33, https://doi.org/10.31538/ndh.v5i3.984. Amat Suroso dkk., "Challenges and Opportunities towards an Islamic Cultured Generation: Socio-Cultural Analysis," Linguistics and Culture Review 5, no. 1 (28 Juni 2021): 180-94, https://doi.org/10.37028/lingcure.v5n1.1203. Sardjana Orba Manullang, Mardani Mardani, dan Aslan Aslan, "The Effectiveness of Al-Quran Memorization Methods for Millennials Santri During Covid-19 in Indonesia," Nazhruna: Jurnal Pendidikan Islam 4, no. 2 (12 Juni 2021): 195-207, https://doi.org/10.31538/nzh.v4i2.1334.

3 Yogesh K. Dwivedi dkk., "Impact of COVID-19 pandemic on information management research and practice: Transforming education, work and life," International Journal of Information Management 55 (2020): 102211. Hifza dan Aslan, The Model of Competitive Advantage Development in Private Islamic Education Institutions Dalam "BAS A 2019: Proceedings of the Third International Seminar on Recent Language, Literature, and Local Culture Studies, BASA, 20-21 September 2019, Surakarta, Central Java, Indonesia (European Alliance for Innovation, 2020).

${ }^{4}$ Chrysi Rapanta dkk., "Online university teaching during and after the Covid-19 crisis: Refocusing teacher presence and learning activity," Postdigital Science and Education 2, no. 3 (2020): 923-45.

$5 \mathrm{Mel}$ Ainscow dan Abha Sandill, "Developing inclusive education systems: The role of organisational cultures and leadership," International journal of inclusive education 14, no. 4 (2010): 401-16. 
online learning with the hope of student learning success. All solutions have to be studied by trial and error. So, the reference must be written from a theoretical and technical point of view in the field. Teachers' ability without support during the pandemic is naive, so by being coordinated by the guardian, students learn no matter how good they are without school leadership. Schools are skilled professionals with the skills to be models for students and parents who sometimes do not understand in crises, so classes are needed. Many guardians of students will not have this strategy, and they will not be able to cope with the complexities of learning from home in accompanying students with technology tools, which educators often use in schools. ${ }^{6}$ The routine of the student guardians also illustrates how busy the guardians are with the daily routine of starting, enjoying the suspension of each student assignment, and completing certain exercises from specific delivery. To make matters worse, if the online learning created is an improvement, the gap between results and student achievement could widen. Therefore, we need to support educators and parents working together to relieve students' and parents' freedom with acceptable and evidence-based strategic solutions to field studies to solve challenges posed during pandemics and other crises in Indonesia. ${ }^{7}$

\section{METHOD}

The primary goal of this research is to discover school leadership methods to assist children learning from home throughout the pandemic. To address the issues raised above, we looked at hundreds of publications interested in addressing educational disruption during a pandemic, when the effect of the epidemic compels students to study from home, with all the difficulties it entails. We collect data from internet searches and use a phenomenological method to analyze it. ${ }^{8}$ We used a coding system to analyze the data and determine precisely how school leaders reacted to the epidemic. Based on the data and conversations, we discovered that there are many things that schools can and should do that do not need guidance from central state policymakers. We used secondary data from many well-known publications that address education, school policy, and leadership in supporting the deployment of online alternative education during the pandemic response to construct this research is a descriptive qualitative manner. Our data was gathered via electronic searches in various publications, including Sagepub, ERIC, Google Book, and Taylor \& France. We use the qualitative education data review research methodology to execute and present the findings. ${ }^{9}$

\footnotetext{
6 Tamara J. Moore dkk., "Implementation and integration of engineering in K-12 STEM education," dalam Engineering in pre-college settings: Synthesizing research, policy, and practices (Purdue University Press, 2014), 35-60.

${ }^{7}$ Melissa Bond, "Schools and emergency remote education during the COVID-19 pandemic: A living rapid systematic review.," Asian Journal of Distance Education 15, no. 2 (2020): 191-247.

${ }^{8}$ JIBAN Shrestha dkk., "Conservation agriculture as an approach towards sustainable crop production: A review," Farming and Management 5, no. 1 (2020): 7-15.

9 Cecilia Vindrola-Padros dkk., "Carrying out rapid qualitative research during a pandemic: emerging lessons from COVID-19," Qualitative health research 30, no. 14 (2020): 2192-2204.
} 


\section{RESULTS AND DISCUSSION}

This section presents data on a study of several paper articles from well-known publishers concerned about publishing issues of education disrupted by the pandemic.

\section{School Leadership Framework}

Researchers observed that when the epidemic hit the world of education, many schools tried to respond quickly and adequately to serve their communities in meeting needs, such as Telkomsel's connection package allocation policy when the COVID-19 outbreak spread in each country. ${ }^{10}$ One of the government-owned Public institutions affected by the outbreak is schools and universities. However, most schools in regions and cities have little or no facilities to prepare for a crisis and pandemic disruption because so far, they have never faced a problem of this magnitude and escalation, especially with the policy of sending students home suddenly and studying remotely. This summarizes our findings from studies with schools around the world about their response framework during the early months of a pandemic outbreak. ${ }^{11}$

The main challenges are facing each country focus on the response vision and problem characteristics, communication and student family environment, concern for school staff, encouragement of distance learning strategies, maximum communication development, methods of organized school leadership, and confirmation of future possibilities. Possibility forward if there are no signs of a decline in the pandemic. Reports from many countries align with evaluations of crisis authorities during the wider pandemic and have far-reaching implications for leadership for future perspectives on pioneering schools, practices, and support systems in the COVID-19 crisis. ${ }^{12}$ Reduce one-on-one interactions with instructors; difficulty determining the level of student involvement; limited capacity to track individual student progress. The ideal response that schools should take is, for example, the school to establish communication were asking the guardians of students were to carry out higher supervision on children's activities, meeting student needs and increasing isolation at home, donating facilities for children with special needs, assisting access to technology, such as equipment distance learning, gadgets, at various levels to assist learning and work assignments. $^{13}$

Observations also show that Covid-19 has created significant difficulties for the implementation of home education. ${ }^{14}$ By focusing on educational leadership, which is very important not to argue with, of all the currently complex parts, namely the ways and approaches taken to alleviate the free and troubled while the children are learning at home. Because the pandemic itself has consumed energy and hardship for the government and the public, in terms of being researchers, practitioners, and policymakers, the author rests on the

\footnotetext{
${ }^{10}$ Dindin Solahudin dkk., "Analisis kepemimpinan di Indonesia dalam kerangka tanggap-darurat Covid-19," Penulisan Karya Tulis Ilmiah UIN Sunan Gunung Djati Bandung di Masa Work. From Home Tabun 2020, 2020.

11 Putra dkk., "The Students Learning from Home Experiences during Covid-19 School Closures Policy In Indonesia."

12 Tae Eun Shim dan Song Yi Lee, "College students' experience of emergency remote teaching due to COVID-19," Children and youth services review 119 (2020): 105578.

${ }^{13}$ Wahab Ali, "Online and remote learning in higher education institutes: A necessity in light of COVID-19 pandemic.," Higher education studies 10, no. 3 (2020): 16-25.

14 Tony Bush dkk., "School leadership theories and the Malaysia education blueprint: Findings from a systematic literature review," International Journal of Educational Management, 2018.
} 
purpose of the school leadership element being passed on to the students and parents as long as they have to stay at home. However, they stay online because of the demands of the situation that education cannot be stopped. ${ }^{15}$

According to Silva et al. ${ }^{16}$ to protect students from the spread of Covid-19 in the school environment, the epidemic has imposed social distancing measures or physical distancing in Indonesia. As a result, the purpose of this policy is to limit the spread of the Coronavirus in the community. The Ministry of Education and Culture reacted by implementing a policy of learning from home, through online learning, and the abolition of the National Examination for this year. ${ }^{17}$ The widespread of the Coronavirus in several countries forces us to admit that the world is changing. We can observe how Covid-19 affects technology, business, politics, and education amid a crisis. These changes require us to be prepared, react with attitudes and behavior, and continually learn new things. Indonesia is not alone in its efforts to help students continue to learn and exercise their right to education. Covid 19 has impacted at least 1.5 billion school-age children in 188 countries, including 60 million in ours, according to UNESCO. ${ }^{18}$

\section{Weaknesses of school leadership}

The most surprising aspect of the pandemic crisis drive is, as García-Alberti et., al $^{19}$ point out, where they see during a pandemic, student learning outcomes tend to fall. This is none other than equity and the Indonesian government. The government, in this case, not all school leaders can give a pleasant appearance when students and parents are weak. During the Covid-19 crisis, problems arise quickly, and well-established information and action plans may not be sufficient. Unusual concepts in fighting crises (i.e., most school leaders have never experienced pandemics and other emergencies), the rapid course of outbreaks, and dealing with weaknesses that do not support efficient answers are some of the main difficulties for early school pioneers of a pandemic.

The Covid-19 problem has few solutions, initiatives, and components required by crisis solutions. ${ }^{20}$ Shared understanding between school members is fundamental to the solution and anticipation of major crises experienced by students and parents. ${ }^{21}$ Because if school leaders do not have a typical and careful description of the situation, teachers and staff

15 Antonio Narzisi, "Handle the autism spectrum condition during Coronavirus (COVID-19) stay at home period: Ten tips for helping parents and caregivers of young children" (Multidisciplinary Digital Publishing Institute, 2020).

${ }^{16}$ Petrônio CL Silva dkk., "COVID-ABS: An agent-based model of COVID-19 epidemic to simulate health and economic effects of social distancing interventions," Chaos, Solitons \& Fractals 139 (2020): 110088.

17 Pasi Sahlberg, Finnish Lessons 3. 0: What Can the World Learn from Educational Change in Finland? (Teachers College Press, 2021).

18 Adrijana Visnjic-Jevtic dkk., "Policies and practices of early childhood education and care during the COVID-19 pandemic: Perspectives from five countries," Journal of Childhood, Education \& Society 2, no. 2 (2021): 200-216.

19 Marcos García-Alberti dkk., "Challenges and Experiences of Online Evaluation in Courses of Civil Engineering during the Lockdown Learning Due to the COVID-19 Pandemic," Education Sciences 11, no. 2 (2021): 59 .

20 Simona Tarra, Giampiero Mazzocchi, dan Davide Marino, "Food System Resilience during COVID-19 Pandemic: The Case of Roman Solidarity Purchasing Groups," Agriculture 11, no. 2 (2021): 156.

21 Emma Anderson dan Avneet Hira, "Loss of brick-and-mortar schooling: how elementary educators respond," Information and Learning Sciences, 2020. 
cannot make decisions that are taught and discuss them effectively. So with accessories, administrators and individuals who exist as a whole will not be able to deal with this situation. School leaders often do not have a clear picture of what is going on, and they are not used to sharing what they know with other leaders in a way that elicits positive responses and convincing affiliations to solve problems. There are many long stories about hired teachers and school principals trying to get knowledge and guidance from those above them in the educational framework or other school leaders to relevant agencies and their local governments during the first few months of the pandemic. These things determine the low number of problem solutions. ${ }^{22}$

Another important finding from the school leadership crisis is that what makes outstanding schools often thrive during crises is surrender to pandemic crises. ${ }^{23}$ Schools should be at the forefront of adapting to emergencies and school needs from the epidemic crisis. Some school pioneers, for example, went through several essential reaction phases during the early months of the COVID-19 epidemic. ${ }^{24}$ The first stage focuses on the coming outbreak. This is the most critical time, such as interacting with children and families, school leadership must get recognition from students and parents to get a way of communicating remotely, and schools must monitor the progress and development of the family. During Phase II, school directors must reorganize their work agenda to support students and families. In this way, school directives can be forwarded remotely. ${ }^{25}$ This effort prepares teacher councils for approaches and strategies towards advancing new adaptable ways of learning and creates an enlightening schedule and third stage for operating with digital and web-based learning. As school leadership begins to adjust to the new schedule, pioneering schools can focus on more targeted and more crucial online learning opportunities for students to predict future opportunities and assist their relationship with preparation for future coaching detachments. ${ }^{26}$

\section{Emergency Leadership}

The findings we quote here from various contexts in many countries also apply to Indonesia's domestic education system. During the education disruption emergency in Indonesia, school leadership, like fellow teachers and other elements, must communicate what students need, work smartly on alert in a pandemic-vulnerable situation, and be flexible and dynamic in concentrating on school progress and student welfare. And parents. Osland et al. ${ }^{27}$ describe the duties of school leaders as necessary to school organizations and their principals,

\footnotetext{
22 Abraham David Benavides dan Julius A. Nukpezah, "How local governments are caring for the homeless during the COVID-19 pandemic," The American Review of Public Administration 50, no. 6-7 (2020): 650-57.

${ }^{23}$ Jamil Salmi, "COVID's Lessons for Global Higher Education: Coping with the Present While Building a More Equitable Future.," Lumina Foundation, 2020.

${ }^{24}$ Fareed Zakaria, Ten lessons for a post-pandemic world (Penguin UK, 2020).

${ }^{25}$ Estela Costa, Mónica Baptista, dan Carolina Carvalho, "The Portuguese educational policy to ensure equity in learning in times of crises," dalam Primary and Secondary Education During Covid-19 (Springer, 2022), 203-25.

${ }^{26}$ Jalal Ramazani dan George Jergeas, "Project managers and the journey from good to great: The benefits of investment in project management training and education," International Journal of Project Management 33, no. 1 (2015): 41-52.

27 J. S. Osland dkk., "Perspectives on global leadership and the Covid-19 crisis," dalam Advances in Global Leadership (Emerald Publishing Limited, 2020).
} 
as is the case in other cultural domains. Apart from a denser study base, several emergency initiatives tests have been carried out specifically in schools in Indonesia, especially in cities where the equipment facilities are adequate.

Evidence of school support, for example, is cited by Wijaya \& Andarini, ${ }^{28}$ on medical experiences as historical actors and medical aid providers during the 2004 tsunami emergency response phase. They articulated a three-factor model of school crisis authority based on a study of the actions of school leaders after the pandemic. The most crucial element is dispositional and consists of the school's pioneering qualities, belief systems, character, abilities, and subjects. The next component is the vision of social leadership, strengthening and facilitation of workforce development from schools, building trust, strengthening defenses, and creating a sense of togetherness and sharing. The last element is a conditioning, which involves appreciating the context of experience and services and the present context, adapting to dynamic needs, thinking creatively, and directing leadership connections. Fitrianti, ${ }^{29}$ found explicit organizational exercises included in all of these sections during situational assessments in four primary schools. In a separate study published in the same year, Fajriyah \& Putri, ${ }^{30}$ in their study "My Teacher is a Hero During the Covid-19 Pandemic. Efforts to Provide Optimal Counseling Teachers during the Covid-19 Pandemic," also found that schools with a culture that includes all and strong connections are better equipped to tackle potential problems ahead of time.

\section{Online instructions for teachers, parents}

The discoveries of Duraku and Hoxha, ${ }^{31}$ say that the effect of the pandemic on the progression of instruction and the soundness of understudies, educators, guardians is not tantamount to the difficulties that should be tended to, like internet learning and openings for propelling the nature of schooling. They guarantee that the progress from school to privately based learning is as proof-based as could be expected. ${ }^{32}$ While advanced education gives an abundance of Evidence to best practice, the proof-based guidelines introduced here give essential data to teachers to consider, especially what parts of electronic realizing are by and large needed to develop understudy learning results and encounters further. In distance schooling, distance learning, and internet preparing (for instance, substantial open online courses, there are numerous speculative procedures and related methodologies proposed for

\footnotetext{
28 Sapondra Wijaya dan Sri Andarini, "Pengalaman Perawat Sebagai Survivor Dan Pemberi Pertolongan Kesehatan Saat Respon Tanggap Darurat Pada Korban Bencana Tsunami Tahun 2004 Di Lhoknga Dan Lhoong Aceh Besar," Wiraraja Medika: Jurnal Kesehatan 5, no. 2 (2015).

${ }^{29}$ Desi Fitrianti, "Harta Bersama dalam Perkawinan Poligami Menurut Undang-Undang Nomor 1 Tahun 1974 dan Hukum Islam,” Jurnal Intelektualita: Keislaman, Sosial dan Sains 6, no. 1 (2017): 83-102.

${ }^{30}$ Faizatun Milianti Fajriyah dan Nur Afifah Arista Putri, "Guruku Pahlawan Dikala Pandemi Covid-19," Usaha Pemberian Layanan yang Optimal Guru BK pada Masa Pandemi Covid-19 (Antologi Esai Mahasiswa Bimbingan dan Konseling), 2021, 153.

31 Zamira Hyseni Duraku dan Linda Hoxha, "The impact of COVID-19 on education and on the well-being of teachers, parents, and students: Challenges related to remote (online) learning and opportunities for advancing the quality of education," Manuscript submitted for publication]. Faculty of Philosophy, University of Prishtina, 2020.

32 Ying Zhao dkk., "The effects of online homeschooling on children, parents, and teachers of grades 1-9 during the COVID-19 pandemic," Medical Science Monitor: International Medical Journal of Experimental and Clinical Research 26 (2020): e925591-1.
} 
managing understudies distantly. ${ }^{33}$ Improvement of frameworks and approaches information upholds unequivocal utilization of web/distance showing parts Evidence of what works as far as understudy results and what understudies/teachers find compelling in on the web/distance learning can help instructors who experience issues changing their taking in spaces from long, eye to eye figuring out the how-to on the web or distance learning. ${ }^{34}$

There are quality criteria for web/distance education. Confirmation argues that web/distance guides work best as various interconnected dynamic parts that can change as far as execution goes by changing settings. ${ }^{35}$ These sections work together to provide a directed learning climate by demonstrating strategies and combining various exercises, taking into account adaptable delivery. ${ }^{36}$ If needed, the constituent components can be changed, connected, or removed; for example, independent learning cannot be used without fail, or reflection exercises can be combined with multiple student collaborations. ${ }^{37}$ Using this method, teachers can modify their delivery of material to suit their particular learning system. Three types of associations in distance education are widely considered necessary for program progress and transportation student content, students, and student instructors. ${ }^{38}$ These coordinated efforts must be addressed at every stage of the online/distance learning preparation process, and they are interwoven into every component of the normal-time approach. For example, internet content can be disseminated as a fun activity that connects mini student gatherings in a way intended to promote packet debate, contemplation, and friendly communication. As a result, the instructor can use the model shown to think about how the various components of e-learning might work together.

\section{Community shared learning}

Individual learning refreshes understudy learning more than localized learning in online environments. ${ }^{39}$ Because research shows that understudy connection (with each other or with the instructor) is not a panacea, but rather a mechanical assembly that should be used correctly and as the specific learning process coordinates, the affiliation idea is essential. Since a consequence, biological activities and collaboration/joint effort should be incorporated in the transportation of learning information at all levels, as forced or abuse of relationships in an online/distance connection may be seen adversely by understudies. There are, nevertheless, a variety of mechanical options for empowering written exertion and accelerating connections

33 Cyril Brom dkk., "Mandatory home education during the COVID-19 lockdown in the Czech Republic: a rapid survey of 1st-9th Graders' parents," dalam Frontiers in Education, vol. 5 (Frontiers, 2020), 103.

34 Gwendoline Vusumuzi Nani dan Lwazi Sibanda, "Online Home Schooling: Are Parents Ready? Lessons from the Corona Virus Disease Induced Lock Down," Randwick International of Education and Linguistics Science Journal 1, no. 2 (2020): 140-51.

35 Hussain Saleem dkk., "Data Science and Machine Learning Approach to Improve E-Commerce Sales Performance on Social Web," International Journal of Computer Science and Network Security (IJCSNS) 19 (2019).

${ }^{36}$ Istaryaningtyas Istaryaningtyas, L. Silviana, dan E. Hidayat, "Management of the Independent Learning Curriculum during the Covid-19 Pandemic," Journal of Education Research and Evaluation 5, no. 2 (2021).

${ }^{37}$ Alberta Aseye Ama Duhoe, Regina Owusu-Afriyie, dan Erica Kumi, "Examining the significance of online and distance learning management in response to crisis in education," Research Journal in Comparative Education 1, no. 1 (2020): 75-90.

38 Clare Buckley Flack dkk., "Socioeconomic disparities in Australian schooling during the COVID-19 pandemic," Melbourne, Australia: Pivot Professional Learning, 2020.

39 Barbara Means, "Technology and education change: Focus on student learning," Journal of research on technology in education 42, no. 3 (2010): 285-307. 
among understudies (and with the instructor), so utilize creative options that are usually appropriate to educators' and understudies' wants and limitations.

\section{Screen time}

The emphasis on quantity has lately moved to quality in discussions about screen usage. Watchmen and professionals who work with children have previously focused their overcoming skepticism on the potential harm to children's development views. According to ongoing studies, this approach to risk and harm is no longer relevant. ${ }^{40}$ Take everything into account, and it is more appropriate to evaluate both the material and the participations that youngsters consume/check out on the Internet. This change in emphasis includes providing more nuanced guidance to the two watchmen and teaching specialists, which has been missing owing to the limited focus on risk balance. The two instructors and gatekeepers should make the following requests when evaluating what their children/understudies are doing on the Internet. What is the unique circumstance? Where, when, and how is advanced material obtained?

During this period of massive change in coaching, these demands provide guards and teachers with a framework for distinguishing between dangerous and typical growth uses. Fundamentally, these exams are included in the already established electronic learning standards. Educators can be confident that their understudies spend virtual learning from home will earnestly support the learning activities and success by creating an online neighborhood that benefits genuine, natural experiences (between understudies, understudies, and the teacher, understudies, and the substance).

\section{CONCLUSION}

This paper aims to identify the school's leadership strategy in supporting students to learn from home during the pandemic using a publication review. We got the results, among others, of how the school framework in responding to the difficult times due to the pandemic from all phases was disrupted. Another result is the weakness of school leadership in responding to the pandemic so that many students and parents are in trouble after the pandemic outbreak. We also raise emergency leadership so that there will be mutual understanding in the future, the interaction of all learning communities on internet connections, sharing learning communities during the pandemic, and screen time on strengthening lessons. Hopefully, the findings of this leadership school will be helpful in the development of educational leadership studies in responding to pandemic disasters and other crises.

\section{REFERENCES}

Ainscow, Mel, dan Abha Sandill. "Developing inclusive education systems: The role of organisational cultures and leadership." International journal of inclusive education 14, no. 4 (2010): 401-16.

Ali, Wahab. "Online and remote learning in higher education institutes: A necessity in light of COVID-19 pandemic." Higher education studies 10, no. 3 (2020): 16-25.

40 Sonia Livingstone dan Alicia Blum-Ross, "Parents' role in supporting, brokering or impeding their children's connected learning and media literacy," Cultural Science Journal 11, no. 1 (2019). 
Anderson, Emma, dan Avneet Hira. "Loss of brick-and-mortar schooling: how elementary educators respond." Information and Learning Sciences, 2020.

Aslan, Aslan, Silvia Silvia, Budi Sulistiyo Nugroho, M. Ramli, dan Rusiadi Rusiadi. “TEACHER'S LEADERSHIP TEACHING STRATEGY SUPPORTING STUDENT LEARNING DURING THE COVID-19 DISRUPTION." Nidhomul Haq: Jurnal Manajemen Pendidikan Islam 5, no. 3 (21 November 2020): 321-33. https://doi.org/10.31538/ndh.v5i3.984.

Benavides, Abraham David, dan Julius A. Nukpezah. "How local governments are caring for the homeless during the COVID-19 pandemic." The American Review of Public Administration 50, no. 6-7 (2020): 650-57.

Bond, Melissa. "Schools and emergency remote education during the COVID-19 pandemic: A living rapid systematic review." Asian Journal of Distance Education 15, no. 2 (2020): 191-247.

Bozkurt, Aras, Insung Jung, Junhong Xiao, Viviane Vladimirschi, Robert Schuwer, Gennady Egorov, Sarah Lambert, Maha Al-Freih, Judith Pete, dan Don Olcott Jr. "A global outlook to the interruption of education due to COVID-19 pandemic: Navigating in a time of uncertainty and crisis." Asian Journal of Distance Education 15, no. 1 (2020): 1 126.

Brom, Cyril, Jirí Lukavskỳ, David Greger, Tereza Hannemann, Jana Straková, dan Roman Švarríček. "Mandatory home education during the COVID-19 lockdown in the Czech Republic: a rapid survey of 1st-9th Graders' parents." Dalam Frontiers in Education, 5:103. Frontiers, 2020.

Bush, Tony, Suriani Abdul Hamid, Ashley Ng, dan Maria Kaparou. "School leadership theories and the Malaysia education blueprint: Findings from a systematic literature review." International Journal of Educational Management, 2018.

Costa, Estela, Mónica Baptista, dan Carolina Carvalho. "The Portuguese educational policy to ensure equity in learning in times of crises." Dalam Primary and Secondary Education During Covid-19, 203-25. Springer, 2022.

Duhoe, Alberta Aseye Ama, Regina Owusu-Afriyie, dan Erica Kumi. "Examining the significance of online and distance learning management in response to crisis in education." Research Journal in Comparative Education 1, no. 1 (2020): 75-90.

Duraku, Zamira Hyseni, dan Linda Hoxha. "The impact of COVID-19 on education and on the well-being of teachers, parents, and students: Challenges related to remote (online) learning and opportunities for advancing the quality of education." Manuscript submitted for publication]. Faculty of Philosophy, University of Prishtina, 2020.

Dwivedi, Yogesh K., D. Laurie Hughes, Crispin Coombs, Ioanna Constantiou, Yanqing Duan, John S. Edwards, Babita Gupta, Banita Lal, Santosh Misra, dan Prakhar Prashant. "Impact of COVID-19 pandemic on information management research and practice: Transforming education, work and life." International Journal of Information Management 55 (2020): 102211.

Fajriyah, Faizatun Milianti, dan Nur Afifah Arista Putri. "Guruku Pahlawan Dikala Pandemi Covid-19." Usaba Pemberian Layanan yang Optimal Guru BK pada Masa Pandemi Covid-19 (Antologi Esai Mahasiswa Bimbingan dan Konseling), 2021, 153.

Fethullah, Gulen. "Education from cradle to grave - Fethullah Gülen's Official Web Site." Diakses 28 Mei 2019. https://fgulen.com/en/fethullah-gulens-works/toward-aglobal-civilization-of-love-and-tolerance/education/25271-education-from-cradle-tograve. 
Fifi, Nofiaturrahmah. "Model Pendidikan Karakter di Pesantren (Studi Pondok Pesantren AlMunawwir Krapyak dan Muallimin Muallimat Yogyakarta." Doctoral, UIN Sunan Kalijaga, 2015. http://digilib.uin-suka.ac.id/23812/.

Fitrianti, Desi. "Harta Bersama dalam Perkawinan Poligami Menurut Undang-Undang Nomor 1 Tahun 1974 dan Hukum Islam." Jurnal Intelektualita: Keislaman, Sosial dan Sains 6, no. 1 (2017): 83-102.

Flack, Clare Buckley, Lyndon Walker, Amanda Bickerstaff, dan Cara Margetts. "Socioeconomic disparities in Australian schooling during the COVID-19 pandemic." Melbourne, Australia: Pivot Professional Learning, 2020.

García Vazquez, Alain, Juan M. Verde, Francesca Dal Mas, Mariano Palermo, Lorenzo Cobianchi, Jacques Marescaux, Benoit Gallix, Bernard Dallemagne, Silvana Perretta, dan Mariano E. Gimenez. "Image-guided surgical e-learning in the post-COVID-19 pandemic era: what is next?" Journal of Laparoendoscopic \& Advanced Surgical Techniques 30, no. 9 (2020): 993-97.

García-Alberti, Marcos, Fernando Suárez, Isabel Chiyón, dan Juan Carlos Mosquera Feijoo. "Challenges and Experiences of Online Evaluation in Courses of Civil Engineering during the Lockdown Learning Due to the COVID-19 Pandemic." Education Sciences 11, no. 2 (2021): 59.

Hifza dan Aslan. The Model of Competitive Advantage Development in Private Islamic Education Institutions Dalam "BASA 2019: Proceedings of the Third International Seminar on Recent Language, Literature, and Local Culture Studies, BASA, 20-21 September 2019, Surakarta, Central Java, Indonesia. European Alliance for Innovation, 2020.

Istaryaningtyas, Istaryaningtyas, L. Silviana, dan E. Hidayat. "Management of the Independent Learning Curriculum during the Covid-19 Pandemic." Journal of Education Research and Evaluation 5, no. 2 (2021).

Lickona, Thomas. Educating for Character: How Our Schools Can Teach Respect and Responsibility. New York: Bantam Books, 2009.

Livingstone, Sonia, dan Alicia Blum-Ross. "Parents' role in supporting, brokering or impeding their children's connected learning and media literacy." Cultural Science Journal 11, no. 1 (2019).

Ma arif, Muhammad Anas, dan Ari Kartiko. "Fenomenologi Hukuman di Pesantren : Analisis Tata Tertib Santri Pondok Pesantren Daruttaqwa Gresik." Nadwa 12, no. 1 (22 Juni 2018): 181-96. https://doi.org/10.21580/nw.2018.12.1.1862.

Manullang, Sardjana Orba, Mardani Mardani, dan Aslan Aslan. "The Effectiveness of AlQuran Memorization Methods for Millennials Santri During Covid-19 in Indonesia." Ną̧hruna: Jurnal Pendidikan Islam 4, no. 2 (12 Juni 2021): 195-207. https://doi.org/10.31538/nzh.v4i2.1334.

Means, Barbara. "Technology and education change: Focus on student learning." Journal of research on technology in education 42, no. 3 (2010): 285-307.

Moore, Tamara J., Micah S. Stohlmann, Hui Hui Wang, Kristina M. Tank, Aran W. Glancy, dan Gillian H. Roehrig. "Implementation and integration of engineering in K-12 STEM education." Dalam Engineering in pre-college settings: Synthesizing research, policy, and practices, 35-60. Purdue University Press, 2014.

Nani, Gwendoline Vusumuzi, dan Lwazi Sibanda. "Online Home Schooling: Are Parents Ready? Lessons from the Corona Virus Disease Induced Lock Down.” Randwick International of Education and Linguistics Science Journal 1, no. 2 (2020): 140-51.

Narzisi, Antonio. "Handle the autism spectrum condition during Coronavirus (COVID-19) stay at home period: Ten tips for helping parents and caregivers of young children." Multidisciplinary Digital Publishing Institute, 2020. 
Osland, J. S., M. E. Mendenhall, B. S. Reiche, Betina Szkudlarek, Richard Bolden, Polly Courtice, Vlad Vaiman, M. Vaiman, D. Lyndgaard, dan K. Nielsen. "Perspectives on global leadership and the Covid-19 crisis." Dalam Advances in Global Leadership. Emerald Publishing Limited, 2020.

Putra, Purniadi, Fahrina Yustiasari Liriwati, Tasdin Tahrim, Syafrudin Syafrudin, dan Aslan Aslan. "The Students Learning from Home Experiences during Covid-19 School Closures Policy In Indonesia." Jurnal Iqra': Kajian Ilmu Pendidikan 5, no. 2 (5 September 2020): 30-42. https://doi.org/10.25217/ji.v5i2.1019.

Ramazani, Jalal, dan George Jergeas. "Project managers and the journey from good to great: The benefits of investment in project management training and education." International Journal of Project Management 33, no. 1 (2015): 41-52.

Rapanta, Chrysi, Luca Botturi, Peter Goodyear, Lourdes Guàrdia, dan Marguerite Koole. "Online university teaching during and after the Covid-19 crisis: Refocusing teacher presence and learning activity." Postdigital Science and Education 2, no. 3 (2020): 923-45.

Sahlberg, Pasi. Finnish Lessons 3. 0: What Can the World Learn from Educational Change in Finland? Teachers College Press, 2021.

Saleem, Hussain, Khalid Bin Muhammad, Altaf Hussain Nizamani, Samina Saleem, dan A. M. Aslam. "Data Science and Machine Learning Approach to Improve E-Commerce Sales Performance on Social Web." International Journal of Computer Science and Network Security (IJCSNS) 19 (2019).

Salmi, Jamil. "COVID's Lessons for Global Higher Education: Coping with the Present While Building a More Equitable Future." Lumina Foundation, 2020.

Shim, Tae Eun, dan Song Yi Lee. "College students' experience of emergency remote teaching due to COVID-19." Children and youth services review 119 (2020): 105578.

Shrestha, JIBAN, SUBASH Subedi, Krishna Prasad Timsina, Amit Chaudhary, Manoj Kandel, dan Subina Tripathi. "Conservation agriculture as an approach towards sustainable crop production: A review." Farming and Management 5, no. 1 (2020): 7-15.

Silva, Petrônio CL, Paulo VC Batista, Hélder S. Lima, Marcos A. Alves, Frederico G. Guimarães, dan Rodrigo CP Silva. "COVID-ABS: An agent-based model of COVID19 epidemic to simulate health and economic effects of social distancing interventions." Chaos, Solitons \& Fractals 139 (2020): 110088.

Solahudin, Dindin, Dang Eif Saiful Amin, Deden Sumpena, dan Fathin Anjani Hilman. "Analisis kepemimpinan di Indonesia dalam kerangka tanggap-darurat Covid-19." Penulisan Karya Tulis Ilmiah UIN Sunan Gunung Djati Bandung di Masa Work From Home Tabun 2020, 2020.

Suroso, Amat, Prasetyono Hendriarto, Galuh Nashrulloh Kartika Mr, Petrus Jacob Pattiasina, dan Aslan Aslan. "Challenges and Opportunities towards an Islamic Cultured Generation: Socio-Cultural Analysis." Linguistics and Culture Review 5, no. 1 (28 Juni 2021): 180-94. https://doi.org/10.37028/lingcure.v5n1.1203.

Tarra, Simona, Giampiero Mazzocchi, dan Davide Marino. "Food System Resilience during COVID-19 Pandemic: The Case of Roman Solidarity Purchasing Groups." Agriculture 11, no. 2 (2021): 156.

Vindrola-Padros, Cecilia, Georgia Chisnall, Silvie Cooper, Anna Dowrick, Nehla Djellouli, Sophie Mulcahy Symmons, Sam Martin, Georgina Singleton, Samantha Vanderslott, dan Norha Vera. "Carrying out rapid qualitative research during a pandemic: emerging lessons from COVID-19." Qualitative health research 30, no. 14 (2020): 2192-2204.

Visnjic-Jevtic, Adrijana, Anikó Varga Nagy, Gulsah Ozturk, İkbal Tuba Şahin-Sak, Jesús PazAlbo, Mehmet Toran, dan Noelia Sánchez-Pérez. "Policies and practices of early 
childhood education and care during the COVID-19 pandemic: Perspectives from five countries." Journal of Childhood, Education \& Society 2, no. 2 (2021): 200-216.

Wijaya, Sapondra, dan Sri Andarini. "Pengalaman Perawat Sebagai Survivor Dan Pemberi Pertolongan Kesehatan Saat Respon Tanggap Darurat Pada Korban Bencana Tsunami Tahun 2004 Di Lhoknga Dan Lhoong Aceh Besar.” Wiraraja Medika: Jurnal Kesehatan 5, no. 2 (2015).

Zakaria, Fareed. Ten lessons for a post-pandemic world. Penguin UK, 2020.

Zhao, Ying, Yong Guo, Yu Xiao, Ranke Zhu, Wei Sun, Weiyong Huang, Deyi Liang, Liuying Tang, Fan Zhang, dan Dongsheng Zhu. "The effects of online homeschooling on children, parents, and teachers of grades 1-9 during the COVID-19 pandemic." Medical Science Monitor: International Medical Journal of Experimental and Clinical Research 26 (2020): e925591-1. 